\title{
Estudio de las variaciones mineralógicas y morfológicas en cenizas volantes provocadas por fenómenos de lixiviación
}

\section{Mineralogical and morphological changes of fly ashes with leaching phenomenon}

\section{RESUMEN}

La investigación se realiza en tres cenizas volantes españolas con contenidos de $\mathrm{CaO}$ entre $2-30 \%$ en peso. Para observar el proceso de lixiviación en estos subproductos industriales se lleva a cabo un ensayo similar al descrito por la EPA-EP. Las aguas lixiviadas se analizan por la técnica ICP, mientras que los residuos se caracterizan por difracción de rayos X y SEM-EDX.

El estudio se centra en el seguimiento de los elementos más solubles, según la metodología aplicada, y en la formación de nuevas fases cristalinas secundarias. Además, se confirma la relación existente entre el $\mathrm{pH}$ de la disolución $y$ el porcentaje de elemento extraído.
SUMMARY

In this study, three Fly Ashes (FA) from Spanish Power Plants with $\mathrm{CaO}$ contents between 2-30\% in weight were examined. They were leached using a variation on EPA-EP leaching test, checking the influence of the leaching process on FA. Leaches were analysed by ICP. XRD and SEM-EDX technique were used to analyse the leached FA.

The study carried out was mainly centred in following the evolution of the most soluble elements and the formation of new secondary crystalline phases. The relationship between dissolution $\mathrm{pH}$ and the percentage of the extracted element was also confirmed.

\section{INTRODUCCIÓN}

Durante los últimos treinta años la cantidad de residuos que se generan son cada vez mayores, especialmente en los países industrializados; hecho que preocupa tanto a la administración como al sector industrial y a la opinión pública.

El aprovechamiento de cualquier subproducto generado durante un proceso industrial tiene en la actualidad carácter prioritario. Una de las forma de reciclar estos materiales, es buscar aplicaciones concretas de uso que sean factibles con las características de los mismos.

\section{INTRODUCTION}

During the last 30 years, the amount of wastes generated is progressively larger, especially in industrial countries; this fact is increasingly worrying the administration as well as the industries and public opinion.

The recycling of any by-product generated during an industrial process is a priority. One of the forms of recycling these materials is to find definite applications according to the materials characteristics. 
Así, la industria cementera ha sido pionera en la reutilización de subproductos industriales en la fabricación de cementos hidráulicos, con el consiguiente ahorro energético, existiendo pruebas del buen comportamiento de estos materiales en la durabilidad de los cementos y hormigones, a los que confieren mejoras en ciertas propiedades. Este hecho se refleja en la normativa, tanto española como internacional, donde aparecen cementos en cuya composición forman parte diferentes subproductos industriales (1-2).

El aprovechamiento de residuos industriales en la industria cementera con garantías de respetar la protección medioambiental exige realizar estudios que contemplen tanto el posible efecto de fijación de los elementos nocivos durante la hidratación del cemento, como el comportamiento de estas adiciones con el deslavado y la contaminación de las aguas potables.

En este sentido, la unión europea de asociaciones nacionales de distribuidores de agua (EUREAU) y el Comité Técnico de Cementos y Cales (TC-51), discuten y expresan su preocupación por la posible contaminación producida por la presencia de elementos como el plomo, cinc, cromo, cobre, etc. en los cementos.

Sin embargo, que el material contenga elementos no deseables, no significa que éstos puedan ser causantes de una contaminación por lixiviación, ya que pueden encontrarse formando compuestos químicos no solubles o estables en medio acuoso (3).

Los resultados de lixiviación van a depender de factores como: $\mathrm{pH}$, relación material/liquido de contacto, temperatura, tiempo de ensayo, finura, líquido de extracción, y sobre todo del origen del material y del estado en que se encuentren sus elementos químicos (4-5).

Aunque los distintos métodos de lixiviados recogidos en la bibliografia no reproducen las condiciones reales, permiten predecir los elementos químicos más fácilmente lixiviables.

En general, los ensayos de lixiviación pueden dividirse en: ensayos de laboratorio y ensayos de campo. Siendo, los primeros, los más extendidos.

Entre los ensayos de laboratorio destacan los recogidos en U.S. Environmental Protection Agency, Federal Register (6-8), en el que se basan los métodos de la Orden Ministerial de 13 de octubre de 1989 , sobre la caracterización de residuos tóxicos y peligrosos (9).
Thus, cement industry has been the first in the reutilization of by-products in the manufacturing of hydraulic cements with the subsequent save of energy, existing proofs of the good behaviour of these materials in the durability of cements and concrete. This fact is reflected in the spanish and international standards, where cements with different by-products in their composition were included (1-2).

The utilisation of these by-products in the cement manufacturing respecting the environmental care requires the study of the effect of fixing the dangerous elements during cement hydration as well as the behaviour of these additions with the dewashing and pollution of potable water.

In this sense, the European Union of Associations for water distribution (EUREAU) and the Technical Committee of Lime and Cement (TC-51), discuss and express their worry for the possible pollution produced by elements such as led, zinc, chromium, cooper, etc. in cements.

However, the presence of undesirable elements in the material does not mean that pollution by leaching must be produced, because they can be forming insoluble compounds or stable in aqueous medium (3).

The leaching results depend on factors such as: $p H$, material/contact liquid ratio, temperature, test time, fineness, extraction liquid and mainly the material origin and the state of their chemical elements (4-5).

Although the leaching methods collected in bibliography do not simulate real conditions, they provide the prediction of the easiest leaching elements.

In general, the leaching tests can be divided into: laboratory and real tests. The first being the most used.

Among the laboratory tests, those collected in U.S. Environmental Protection Agency, Federal Register (6-8) must be remarked, in which the methods of the Ministerial Order of october, 13, 1989, about the characterisation of toxic and dangerous wastes is based (9). 
Se trata de métodos de lixiviación que tienen por objeto la extracción de las sustancias solubles contenidas en un residuo sólido o pastoso. Estos ensayos consisten básicamente en la agitación continua del residuo sólido en un medio lixiviante, que suele ser agua desionizada, a un $\mathrm{pH}$ controlado, con una relación fija de líquido/sólido y a tiempos prefijados de análisis.

También están los ensayos de lixiviación en columna, donde la muestra sólida se dispone en un tubo, generalmente de plástico y a través del cual se hace pasar el líquido utilizado como lixiviante. Este ensayo pone más en evidencia lo que ocurriría cuando un material es almacenado en escombreras ya que el líquido transcurre por el material de forma semejante a como lo haría el agua de lluvia.

Todos estos métodos mencionados están recogidos en diferentes Normas, principalmente en los Países Bajos, Estados Unidos y Alemania: NEN 7340, NEN 7341, NEN 7343, NEN 7345 y NEN 7349,(10-14); ANS. 16.1 (15); ASTM D 3987 (16); DIN 38414. parte 4 (17). Así como en diferentes trabajos, en los que se ponen de relieve aspectos químicos y mecanismos de lixiviación, destacando los llevados a cabo por H.A. Van Der Sloot (18-25).

Este estudio investiga cenizas volantes producidas en Centrales Termoeléctricas españolas que utilizan carbón como combustible. La selección se efectúa de acuerdo con el contenido de $\mathrm{CaO}$ (cenizas altas y bajas en cal). En estas cenizas, una vez caracterizadas (química, mineralógica y morfológicamente), se lleva a cabo un ensayo de lixiviación para estudiar las variaciones posibles causadas por este fenómeno.

\section{PARTE EXPERIMENTAL}

\section{Material}

\section{- Cenizas volantes (FA)}

Para este estudio se seleccionan cenizas volantes procedentes de tres Centrales Termoeléctricas españolas que utilizan carbones diferentes: antracita, hulla y lignito/antracita.

En la Tabla I se recogen los análisis químicos de los elementos mayoritarios, las composiciones mineralógicas y las finuras de las estas cenizas volantes. La Tabla II muestra las concentraciones de los elementos minoritarios y trazas de estas muestras en su estado inicial antes del lixiviado.
They are leaching methods that aim the extraction of soluble substances content in a solid or slurry waste. These tests are based in the continuous shaking of the solid waste in a leaching medium, usually deionized water, at a controlled $\mathrm{pH}$ with a determined liquid/solid ratio and fixed analysis times.

There are also the leaching tests in column, where the solid sample is placed in a tube, generally a plastic one through which the leaching liquid is passed. This test shows the real situation of materials stored because the test simulates the pass of the rainwater through the material.

All these methods mentioned above are collected in different Standards, mainly, in Low Countries, U.S.A and Germany: NEN 7340, NEN 7341, NEN 7343, NEN 7345 and NEN 7349(10-14), ANS 16.1 (15), ASTM D 3987 (16), DIN 38414 part 4 (17). As well as different works in which chemical aspects and leaching mechanisms are shown, especially those of H.A. Van Der Sloot (18-25).

This study analyses FA generated in spanish Power Plants that use bituminous, anthracite and lignite coals as a power source, selected according to their $\mathrm{CaO}$ content: (high and low in lime). These ashes, once characterised (chemical, mineralogical and morphological characterisation), were submitted to leaching tests to study the possible variations caused by leaching phenomena.

\section{EXPERIMENTAL PART}

\section{Material}

- Fly ashes (FA)

For this study, fly ashes from three spanish Power Plants with different coals(anthracite, bituminous and lignite/anthracite) were selected.

The chemical analysis of major elements, mineralogical compositions and fineness of fly ashes are given in Table I. Also in Table II, minor element concentrations and traces of this fly ashes before the leaching are shown. 
TABLA I (TABLE I)

Análisis químicos (\% en peso), propiedades físicas y mineralogía de las cenizas volantes (FA) (Chemical analysis (\% weight), physical and mineralogical properties of $(F A)$ )

\begin{tabular}{|c|c|c|c|}
\hline & \multicolumn{3}{|c|}{ Cenizas volantes (Fly ashes) } \\
\hline & FA-1 & FA-2 & FA-3 \\
\hline Carbón original (Original coal) & $\begin{array}{l}\text { Antracita) } \\
\text { (Anthracite) }\end{array}$ & $\begin{array}{c}\text { Hulla } \\
\text { (Bituminous) }\end{array}$ & $\begin{array}{c}\text { Lignito/Antracita } \\
\text { (Lignite/Anthracite) }\end{array}$ \\
\hline $\begin{array}{c}\text { Propiedades físicas } \\
\text { (Physical properties) } \\
\text { Finura: (Fineness): } \\
\text { Pasa } 45 \mu \mathrm{m}(\%) \text { (Passing } 45 \mu \mathrm{m}(\%)) \\
\text { Pasa } 90 \mu \mathrm{m}(\%) \text { (Passing } 90 \mu \mathrm{m}(\%))\end{array}$ & $\begin{array}{l}81,4 \\
95,6\end{array}$ & $\begin{array}{l}81,9 \\
94,5\end{array}$ & $\begin{array}{l}85,5 \\
97,4\end{array}$ \\
\hline $\begin{array}{l}\text { Analisis químico (\%) } \\
\text { (Chemical analysis }(\%) \text { ) } \\
\mathrm{SiO}_{2} \\
\mathrm{Al}_{2} \mathrm{O}_{3} \\
\mathrm{Fe}_{2} \mathrm{O}_{3} \\
\mathrm{CaO} \\
\mathrm{SO}_{3} \\
\mathrm{MgO} \\
\mathrm{Na}_{2} \mathrm{O} \\
\mathrm{K}_{2} \mathrm{O} \\
\mathrm{LOI}\end{array}$ & $\begin{array}{c}49,8 \\
23,9 \\
8,4 \\
2,0 \\
0,25 \\
2,3 \\
0,9 \\
4,0 \\
7,0\end{array}$ & $\begin{array}{c}44,5 \\
23,1 \\
10,2 \\
9,9 \\
0,7 \\
2,5 \\
0,3 \\
1,3 \\
7,1\end{array}$ & $\begin{array}{c}38,9 \\
15,3 \\
7,4 \\
29,9 \\
4,1 \\
1,0 \\
0,4 \\
1,9 \\
0,3\end{array}$ \\
\hline $\begin{array}{l}\text { Contenido mineralógico } \\
\text { (Mineralogical content) }\end{array}$ & $\begin{array}{l}\text { Cuarzo } \\
\text { (Quartz) } \\
\text { Mullita } \\
\text { (Mullite) } \\
\text { Hematite } \\
\text { (Hematite) } \\
\text { Magnetita } \\
\text { (Magnetite) }\end{array}$ & $\begin{array}{c}\text { Cuarzo } \\
\text { (Quartz) } \\
\text { Mullita } \\
\text { (Mullite) } \\
\text { Hematite } \\
\text { (Hematite) } \\
\text { Cal libre } \\
\text { (Free lime) } \\
\text { Anhidrita } \\
\text { (Anhidrite) } \\
\text { Portlandita } \\
\text { (Portlandite) } \\
\text { Periclasa } \\
\text { (Periclase) }\end{array}$ & $\begin{array}{c}\text { Cuarzo } \\
\text { (Quartz) } \\
\text { Anhidrita } \\
\text { (Anhidrite) } \\
\text { Cal libre } \\
\text { (Free lime) } \\
\text { Portlandita } \\
\text { (Portlandite) } \\
\text { Hematite } \\
\text { (Hematite) } \\
\text { Calcita } \\
\text { (Calcite) } \\
\text { Silicatos } \\
\text { cálcicos }\left(^{*}\right) \\
\text { (Calcium } \\
\left.\text { silicates }\left(^{*}\right)\right)\end{array}$ \\
\hline
\end{tabular}


TABLA II (TABLE II)

Elementos minoritarios y trazas de las cenizas volantes (ppm)

(Minor and trace elements of fly ashes (ppm))

\begin{tabular}{||c|c|c|c||}
\hline \multirow{2}{*}{$\begin{array}{c}\text { Elementos minoritarios (ppm) } \\
\text { (Minor elements (ppm)) }\end{array}$} & \multicolumn{3}{|c||}{ Cenizas volantes (Fly Ashes) } \\
\cline { 2 - 4 } & FA-1 & FA-2 & FA-3 \\
\hline $\mathrm{Ba}$ & 1300 & 1020 & 220 \\
$\mathrm{Cd}$ & $<1$ & $<1$ & $<1$ \\
$\mathrm{Co}$ & 68 & 69 & 28 \\
$\mathrm{Cr}$ & 177 & 636 & 152 \\
$\mathrm{Cu}$ & 110 & 103 & 45 \\
$\mathrm{Mn}$ & 96 & 223 & 252 \\
$\mathrm{Ni}$ & 149 & 150 & 105 \\
$\mathrm{~Pb}$ & 10 & 9 & 85 \\
$\mathrm{Zn}$ & 125 & 115 & 1 \\
\hline
\end{tabular}

\section{METODOLOGÍA DE ENSAYO}

- Ensayo de lixiviación

El ensayo de lixiviación utilizado en este estudio es una modificación del descrito en la Legislación Española (9), que a su vez está basado en la metodología de ensayo recogida por la Agencia de Protección Medio-Ambiental Americana (EPA) (6).

Este métođo consiste en poner una muestra de ceniza volante en contacto con agua desionizada, con una relación sólido/líquido de 1:16; esta suspensión se mantiene en agitación durante 24 horas. El pH de la misma se ajusta a 5,0 $\pm 0,2$, mediante ácido acético $0,5 \mathrm{~N}$.

La cantidad máxima de ácido acético a añadir no debe exceder 4 veces el peso de la muestra. Sin embargo, en la ceniza volante FA-3, con el volumen máximo de este ácido, no es posible disminuir el $\mathrm{pH}$ por debajo de 12,5, esto es debido a su alto contenido en cal (Tabla I).

Después de este período de tiempo, el líquida se filtra y se diluye con agua desionizada hasta alcanzar 20 veces el peso de sólido. En el líquido y el sólido resultantes se llevan a cabo los análisis pertinentes.

\section{RESULTADOS Y DISCUSIÓN}

\section{Composición química de las cenizas volantes antes y después del ensayo de lixiviación}

La cuantificación química de estos subproductos se lleva a cabo mediante la técnica de espectroscopía de emisión por plasma de acoplamiento inductivo (ICP) (26).

\section{TESTING METHODOLOGY}

\section{- Leaching test}

The leaching process used in this study is a modification of the Spanish Legislation (9), which in turn is based on the testing methodology used by the US Environmental Protection Agency. (EPA) (6).

This method consists in placing a sample of $F A$ in contact with deionized water so that the solid: liquid ratio is 1:16, maintaining it in suspension, shaking continuously for 24hours. The $\mathrm{pH}$ is maintained at $5.0 \pm 0.2$ using $0.5 \mathrm{~N}$ acetic acid solution.

The amount of this acid added must not exceed 4 times the weight of the sample. However, for the sample FA3 , with the maximum volume of added acetic acid, it was not possible to decrease the $\mathrm{pH}$ of the suspension below 12.5, that due to its high CaO content (Table I).

After shaking, the liquid is separated by filtering and diluted in deionized water to 20 times its solid weight. The liquid is analysed and the solid kept for its study.

\section{RESULTS AND DISCUSSION}

\section{Chemical composition of fly ashes before and after the leaching test}

Chemical composition of these materials was determined using the inductively coupled plasma emission spectroscopy technique (ICP) (26). 
Como se observa en la Tabla I y en la Figura 1a, las cenizas volantes seleccionadas tienen contenidos de $\mathrm{CaO}$ diferentes, de forma que FA-1 es una ceniza de bajo contenido en cal (2,0\%), FA-2 de contenido medio $(9,9 \%)$ y $\mathrm{FA}-3$ es una ceniza volante alta en cal $(29,9 \%)$, lo que influye directamente en el contenido de los demás componentes: $\mathrm{SiO}_{2}, \mathrm{AL}_{2} \mathrm{O}_{3}, \mathrm{Fe}_{2} \mathrm{O}_{3}$ y $\mathrm{SO}_{3}$. Este último compuesto aumenta significativamente en la FA-3, alcanzando un 4\%. También existen diferencias en el porcentaje de elementos alcalinos, que es mayor en la ceniza FA-1.

Con respecto a los elementos minoritarios presentes en las cenizas seleccionadas (Fig. 1b), el estudio se centra en los siguientes elementos: $\mathrm{Ba}, \mathrm{Cd}, \mathrm{Co}, \mathrm{Cr}, \mathrm{Cu}, \mathrm{Mn}, \mathrm{Ni}$, $\mathrm{Pb}$ y $\mathrm{Zn}$. Las cenizas de bajo y moderado contenido en cal, el Ba es el elemento mayoritario (>1.000 ppm), seguido de $\mathrm{Cr}$ y $\mathrm{Mn}$. La ceniza alta en cal presentaba contenidos de $\mathrm{Ba} 4$ veces más bajos que las anteriores $(<250 \mathrm{ppm})$.

La Figura 1c muestra los porcentajes lixiviados para cada uno de los elementos considerados. Los cambios químicos causados en el proceso de lixiviación son importantes. Como era de esperar, las cantidades lixiviadas disminuyen con el aumento del valor del $\mathrm{pH}$ (de la FA-1 y FA-2 a la FA-3). En términos generales, se observa que los elementos más solubles son calcio y magnesio, entre los elementos mayoritarios, y manganeso, cobalto, níquel y cromo entre los elementos minoritarios (27).

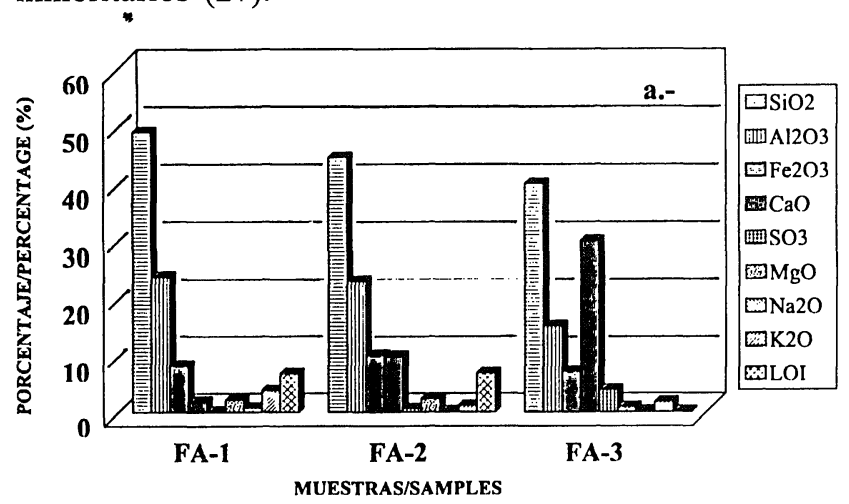

As it is observed in Table I and Figure 1a, fly ashes chosen have different $\mathrm{CaO}$ contents, being $F A-1$ a fly ash with low lime content (2.0\%), FA-2 a fly ash with intermediate lime content (9.9\%) and FA-3 one with high lime content $(29.9 \%)$, which has a direct influence on the content of the other elements: $\mathrm{SiO}_{2}, \mathrm{AL}_{2} \mathrm{O}_{3}, \mathrm{Fe}_{2} \mathrm{O}_{3}$ y $\mathrm{SO}_{3}$. The last component increases significantly in FA-3 reaching 4\%. Also, differences exist in the percentage of alkaline elements, which is higher in FA-1 fly ash.

With respect to the minor elements present in the chosen fly ashes (Fig. Ib), the study is centred in the following elements: $\mathrm{Ba}, \mathrm{Cd}, \mathrm{Co}, \mathrm{Cr}, \mathrm{Cu}, \mathrm{Mn}, \mathrm{Ni}, \mathrm{Pb}$ and $\mathrm{Zn}$. The ashes with low and moderate lime content, $\mathrm{Ba}$ is the mayor element (> $1.000 \mathrm{ppm})$, followed by $\mathrm{Cr}$ and $\mathrm{Mn}$. The fly ash with high lime content showed Ba contents 4 times lower than the others ones $(<250 \mathrm{ppm})$.

Figure 1c shows the percentages of the leached elements under given conditions. Chemical changes caused by leaching process were substantial. As it was expected, the leached amounts decrease with increasing $p H$ value (from $F A-1$ and $F A-2$ to $F A-3$ ). In general terms, it shows that the most mobile or soluble elements are calcium and magnesium, for the major elements and manganese, cobalt, nickel and chromium among the minor ones (27).

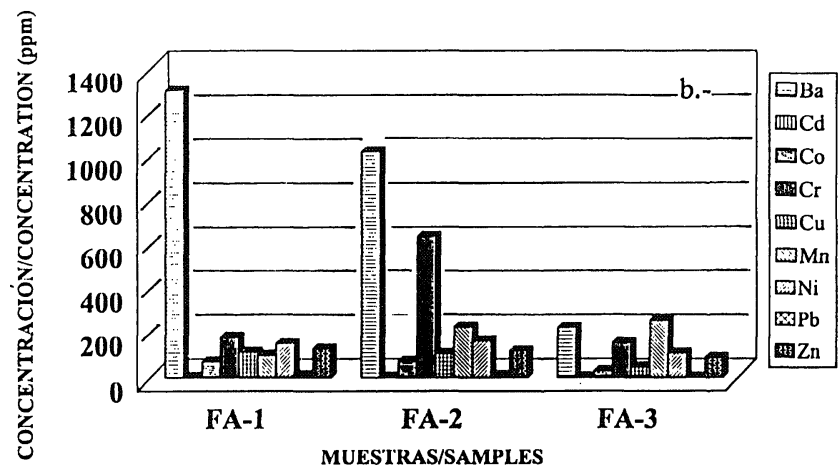

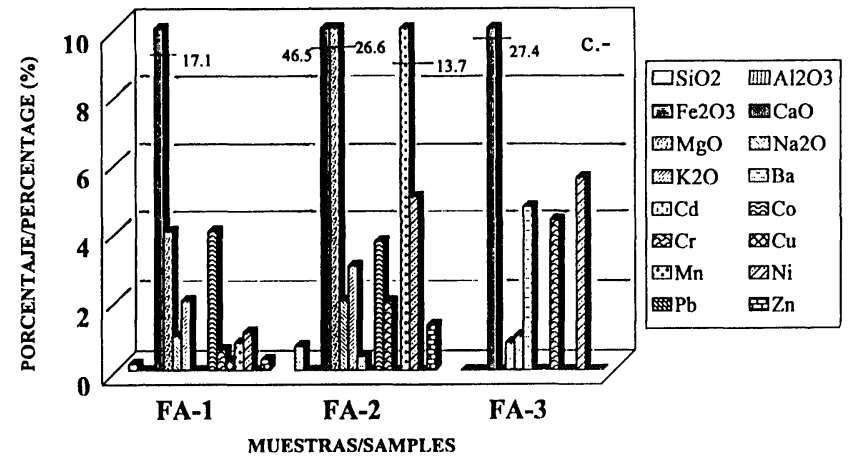

Figura 1.- a) elementos mayoritarios, b) elementos minoritarios, c) elementos mayoritarios y minoritarios lixiviados.

Figure 1.- a) major elements, b) minor elements, c) major and minor elements leached. 
Los porcentajes de calcio extraído eran proporcionales al contenido de cal en las cenizas volantes. Sin embargo, en un medio alcalino (FA-3) la cal extraída es sólo del $27 \%$, menor del esperado, por su contenido en cal. En parte, esto puede ser debido a la baja solubilidad del calcio a este $\mathrm{pH}$ y a la formación de calcita secundaria.

En el caso del $\mathrm{Mg}$, la cantidad extraída no está relacionada con su contenido original. Así, en las FA-1 y FA-2 las concentraciones iniciales son muy similares $(2,3$ y $2,5 \%)$ pero las cantidades de $\mathrm{MgO}$ fueron 4,5\% y $26,6 \%$, respectivamente. Este hecho indica que el $\mathrm{Mg}$ está formando parte de compuestos con diferentes solubilidades, ya que, en el caso de estas dos cenizas, el pH de extracción es similar. Sin embargo, en la ceniza alta en cal, la solubilidad de los compuestos de Mg están por debajo de los límites de detección, ya que a pH alcalino este elemento puede estar en forma precipitada.

En las cenizas FA-1 y FA-2, el Co y Zn estaban presentes en las aguas de lixiviación con un porcentaje extraído de alrededor del $4 \%$ y del $1 \%$ respectivamente, y por debajo del límite de detección para la ceniza FA-3.

El Mn es lixiviado en un $1 \%$ y un $14 \%$ en las cenizas FA-1 y FA-2. El lixiviado en FA-2 es 14 veces mayor que en FA-1, a pesar de que su contenido era tan sólo 2 veces más alto. Al igual que en el caso del Co y $\mathrm{Zn}$, el $\mathrm{Mn}$ no es detectado en las aguas de lixiviación de la FA-3. Este fenómeno está relacionado con el $\mathrm{pH}$, a pH $<10,5$ el Mn (II) es la especie dominante, mientras que que a $\mathrm{pH}>10,5$ es el hidróxido la especie dominante (28).

El cromo es uno de los elementos minoritarios más abundantes en las cenizas volantes. A pH ácidos (FA-1 y FA-2) no guardan una relación entre los contenidos iniciales y los contenidos de los lixiviados. Este hecho está relacionado con el estado de oxidación del cromo (cromo soluble: Cr VI y cromo insoluble: Cr III). En un trabajo anterior, los autores (29) pusieron en evidencia la falta de una relación directa entre el Cr VI y Cr III en cementos, debido a la influencia del proceso de fabricación (temperatura, condiciones oxidantes o reductoras, etc.), similar al de la obtención de las cenizas volantes.

Los estudios llevados a cabo en las tres cenizas volantes han puesto de manifiesto que las fases que contienen $\mathrm{K}$ son más lixiviables que las que contienen $\mathrm{Na}$. En todos los casos, los porcentajes de $\mathrm{Na}$ y $\mathrm{K}$ extraídos estaban situados entre $2-4 \%$. En un principio estas cantidades podrían parecer bajas, si se tiene en cuenta que los elementos alcalinos suelen estar presentes formando parte de los sulfatos, los cuales pueden ser fácilmente extraídos con el ensayo utilizado de la EPA.
The percentages of calcium extracted were proportional to $\mathrm{CaO}$ content in fly ashes. However, in an alkaline medium (FA-3) the calcium extracted is only $27 \%$, less than expected from its $\mathrm{CaO}$ content. This fact might be in part due to low solubility of the lime at this $\mathrm{pH}$ and the formation of secondary calcite.

In the case of $\mathrm{Mg}$, the amount extracted is not related to its original content. So, in FA-1 and FA-2, their initial contents are very similar (2.3 and 2.5\%), but the $\mathrm{MgO}$ amount extracted was 4.5 and $26.6 \%$ respectively. This fact indicates that $\mathrm{Mg}$ is forming compounds with different solubilities, because the pH of extraction is similar in the two cases. However, in the fly ash with high lime content, the solubility of $\mathrm{Mg}$ compounds is below detection limits, because this element could be precipitated at alkaline $\mathrm{pH}$.

Co and $\mathrm{Zn}$ were present in the leaching waters about $4 \%$ for $F A-1$ and about $1 \%$ for $F A-2$ and below detection limit for $F A-3$

In FA-1 and FA-2, a $1 \%$ and a $14 \% \mathrm{Mn}$ was leached. FA-2 leachates 14 times more than FA-1 in spite of its initial content was only two times higher. As in the case of Co and $\mathrm{Zn}, \mathrm{Mn}$ is not detected in the leachating water of FA-3. This phenomenon is related with $\mathrm{pH}$. At $\mathrm{pH}<10.5, \mathrm{Mn}$ (II) is the predominant specie, whereas at $\mathrm{pH}>10.5$, the hydroxide is the main specie (28).

Chromium is one of the minor elements more abundant in the fly ashes. At acid pH (FA-1 and FA2) there is no relation among initial and final contents of the leachates. This fact is related with the oxidation state of chrome (Cr VI and Cr III). In a previous work (29), the authors showed that no relationship exits between $\mathrm{Cr} V \mathrm{VI}$ and $\mathrm{Cr}$ III in cements due to the influence of the manufacturing process (temperature, oxidant or reductant conditions, etc.), similar to the obtention of fly ashes.

The studies carried out in the three fly ashes have shown that the phases containing $K$ are slightly more leachable than those containing $\mathrm{Na}$. In all cases, $\mathrm{Na}$ and $K$ percentages were between 2 and $4 \%$. These amounts could seem low considering that alkaline elements should be present in part as sulphates which should be readily extracted from the EPA test. 
Sin embargo, estos resultados están de acuerdo con los obtenidos en trabajos anteriores (23), donde se pone de relieve la influencia del tiempo de lixiviación en el contenido de $\mathrm{Na}$ extraído.

En general, se observa que, en medio básico, los porcentajes de elementos lixiviados son menores que en medio ácido, esto es debido, como ya se sabe, a la formación de especies precipitadas a pH elevados (28).

Elementos analizados pero no detectados fueron $\mathrm{Cd}, \mathrm{Cu}$, $\mathrm{Ni}$ y $\mathrm{Pb}$ para los elementos minoritarios y $\mathrm{Al}$ y Fe para los elementos mayoritarios. En las FA-1 y FA-2 se extrajo una pequeña cantidad de $\mathrm{Si}(<1 \%)$.

\section{Estudio de las cenizas volantes y de los residuos sólidos procedentes del ensayo de lixiviación mediante difracción de rayos $\mathrm{X}$}

En la Figura 2 se muestran los difractogramas de las tres cenizas volantes. En ella se puede ver que las cenizas FA-1y FA-2 son vítreas en su mayor parte. Las bandas difusas se sitúan en el intervalo 20-30 (20), característico de la mayoría de los vidrios silícicos. En la FA-3 este halo se sitúa alrededor de 32 (20). Este desplazamiento es debido a sus diferencias químicas y mineralógicas (30).
However, these results are in agreement with those obtained in a previous paper (23), in this paper was reported the influence of leaching time on the amount of leached $\mathrm{Na}$.

In general, it was observed that in basic medium, the percentages of the elements leached are less than in acid medium, this is due to the formation of precipitates at higher $\mathrm{pH}$ (28).

Constituents analysed but not detected in the leachate were $\mathrm{Cd}, \mathrm{Cu}, \mathrm{Ni}$ and $\mathrm{Pb}$ for minor elements and $A l$ and Fe for mayor elements. In FA-1 and FA-2 a small Si amount (<1\%) was extracted.

\section{Study of fly ashes and solid leaching residues by $X$-ray diffraction}

The diffractograms of the three fly ashes are shown in Figure 2. It can be seen that FA-I and FA-2 are mostly vitreous. The diffuse scattering peaks are centred around 20-30(20), a typical feature of the majority of silica glass. In FA-3, this halo is situated around 32 (20). This displacement is attributed to their different chemical and mineralogical compositions (30).

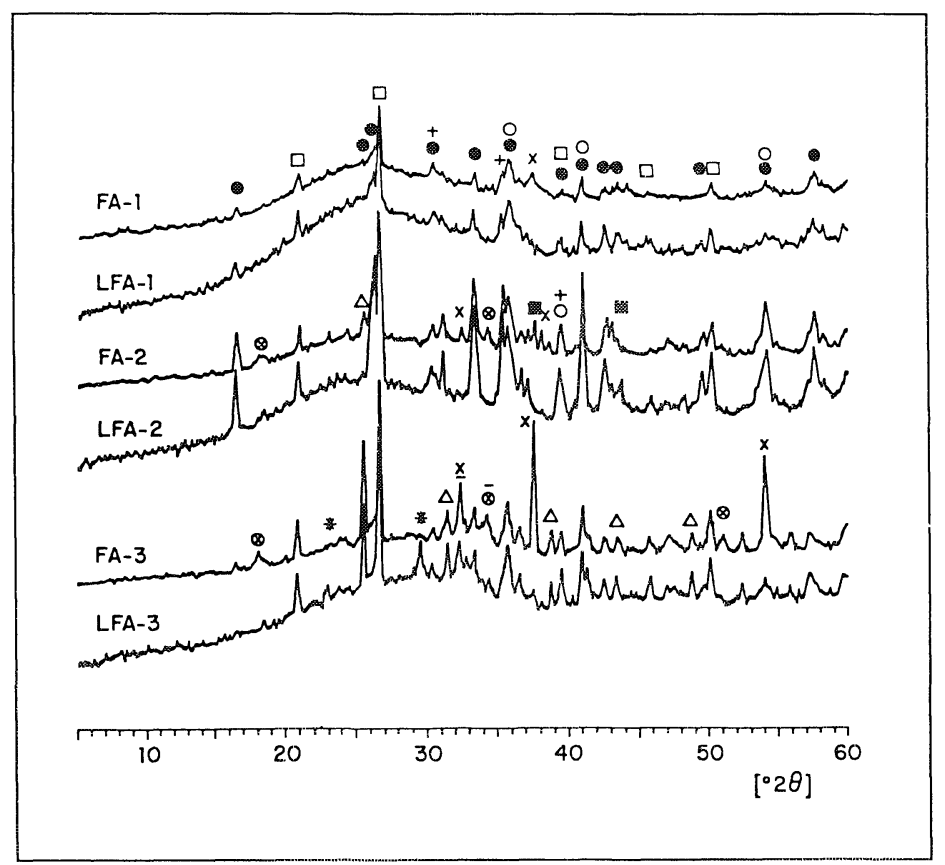

Figura 2.- Difractogramas de RX: IA = ceniza volante; LIA = ceniza volantelixiviada. $\square$ Cuarzo; Mullita; + Magnetita; $O$ Hematite; ${ }^{*}$ Calcita; $A$ Anhidrita; x Cal libre;® Portlandita; - Silicatos cálcicos; Periclasa.

Figure 2--X-Ray Difractograms: FA = fly ash; LFA = leached fly ash. $\square$ Quartz; Mullite; + Magnetite; $\mathrm{O}$ Ilematite; * Calcite; $\triangle$ Anhidrite; $\mathrm{x}$ Free lime; $\otimes$ Portlandite; - Calcium silicates; Periclase. 
En las cenizas volantes FA-1 y FA-2 se identifican: cuarzo, mullita, y pequeñas cantidades de magnetita y hematites. También, en la FA-2 se encontró como fases cristalinas: periclasa, algo de anhidrita, cal libre y portlandita. Es importante mencionar que la mullita es

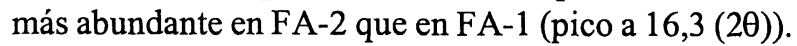

El estudio de la composición química y mineralógica en la ceniza volante FA-3 original, pone de manifiesto que esta muestra es más compleja que las FA-1 y FA-2. La FA- 3 contiene altas cantidades de cuarzo, anhidrita y cal libre $y$, pequeñas cantidades de portlandita, magnetita, hematites y calcita. Otros fases cristalinas, ya recogidas en trabajos previos (31-32), son difíciles de identificar, debido a su baja intensidad o a la superposición de los picos característicos. Así, el $\mathrm{Ca}_{2} \mathrm{SiO}_{4}$ puede estar presente en la ceniza volante original pero sus picos más importantes están solapados con otros compuestos cristalinos como és el caso de la cal libre $(32,6(2 \theta))$ y la portlandita $(34,3(2 \theta))$. Un caso similar ocurre con la gehlenita-akermanita [Ca, $\left.\mathrm{Mg} \mathrm{Al}\left(\mathrm{Si}_{2} 0_{7}\right)\right]$ y anhydrita a $31,4(2 \theta)$ y $31,2(2 \theta)$, respectivamente. No existe una evidencia clara de la presencia de merwinita $\left[\mathrm{Ca}_{3} \mathrm{Mg}\right.$ $\left.\left(\mathrm{SiO}_{4}\right)_{2}\right], \mathrm{C}_{3} \mathrm{~S}, \mathrm{C}_{3} \mathrm{~A}, \mathrm{NaAlSiO}_{4}$ y $\mathrm{KAlSi}_{3} \mathrm{O}_{8}$ (microclina).

Una vez finalizado el ensayo de lixiviación, los difractogramas de las FA-1 y FA-2 lixiviadas (LFA-1 y LFA-2), no difieren de los originales; excepto que el pico de cal libre a 37,7 y los de periclasa a 37,9 y 42,9 (20) desaparecen totalmente en la LFA-2.

La ceniza FA-3, debido a su composición química y mineralógica, se ve más afectada por el proceso de lixiviación. En la figura se aprecia la completa disolución de la cal libre, portlandita y parcialmente de la anhidrita. Mientras que en FA-3, el pico a 32,2 (20) corresponde a la cal libre y el pico a $34,4(2 \theta)$ a la portlandita; en LFA-3 indican la presencia de otros compuestos cristalinos, resistentes a la lixiviación. Uno de estos compuestos podría corresponder con la $\mathrm{Ca}_{2} \mathrm{SiO}_{4}$ (larnita).

Estudios bibliográficos establecen que cuando una ceniza alta en cal es mezclada con agua o hidróxido cálcico pueden producirse productos de hidratación como etringita y yeso, aunque no en todos los casos (32). En la muestra LFA-3, sin embargo, los difractogramas de rayos $\mathrm{X}$ no indicaban la formación de estos compuestos cristalinos.

Este hecho puede estar ligado con la presencia de fases vítreas estables, cuyo proceso de disolución puede ser muy lento, tal es el caso de las fases alumínicas, que controlan la formación de etringita. También, este hecho podría explicarse con la formación de una etringita no cristalina, en períodos de ensayos muy cortos ( $<24$ horas). En el primer caso, los resultados de
In FA-1 and FA-2 identify quartz, mullite and small amounts of magnetite and hematite. Also in FA-2, periclase and some of anhydrite, free lime and portlandite were found as crystalline phases. It is important to mention that the mullite is more abundant in FA-2 that this in FA-1 (peak at 16,3 (20))

Study of the chemical and mineralogical composition of original FA-3, it is shown that this fly ash is more complex compared to the FA-1 and FA-2. The FA-3 contains a high amount of quartz and free lime and, small amounts of potlandite, magnetite, hematite and calcite. Another crystalline phases picked up in previous papers (31-32) are difficult to identify due to either low intensity or overlapping of characteristics peaks. So, $\mathrm{Ca}_{2} \mathrm{SiO}_{4}$ can be present in the original fly ash but theirs main peaks are overlapped with another crystalline compound as free lime (32.6 (2q)) and portlandite $(34.3(2 q))$. Similar case occurs to gehlenite-akermanite $\left[\mathrm{Ca}, \mathrm{Mg} \mathrm{Al}\left(\mathrm{Si}_{2} \mathrm{O}_{7}\right)\right]$ with anhydrite at $31,4(2 q)$ and $31,2(2 q)$, respectively. There is no clear evidence of the presence of merwinite $\left[\mathrm{Ca}_{3} \mathrm{Mg}\left(\mathrm{SiO}_{4}\right)_{2}\right], \mathrm{C}_{3} \mathrm{~S}, \mathrm{C}_{3} \mathrm{~A}, \mathrm{NaAlSiO}_{4}$ and $\mathrm{KAlSi}_{3} \mathrm{O}_{8}$ (miclocline).

Once finished of leaching test, the diffractogram from leached FA-1 and FA-2 (LFA-1 and LFA-2) do not differ from those of the original fly ashes; except that the peak of free lime at 37.72 and periclase at 37.9 and 42.9 (2q) disappear totally in LFA-2.

The FA-3 due to its chemical and mineralogical composition was most affected by leaching process. In figure can be seen the complete dissolution of free lime and portlandite and, partially anhydrite. Whereas in FA-3, the peak at 32.2 (2q) and 34,4 (2q), which are characteristics of free lime and portlandite, in LFA-3 reveals the presence the another crystalline compound, extremely resistant to leaching. One of them could be attributed to $\mathrm{Ca}_{2} \mathrm{SiO}_{4}$ (larnite).

Based on published results when high calcium ash is mixed with water or lime, ettringite and gymsum are likely hydration products but no in all cases (32). However, in LFA-3, the XRD patterns did not show the formation of new crystalline compounds.

This fact can be related with the presence of stable glasses phases, which can produce a very slow dissolution process of the alumina that controls the formation of the ettringite. Also, this phenomenon could associated with the formation of a noncrystalline ettringite at very short time (maximum 24 hours). In first case, the XRD results are in agreement 
rayos X estarían de acuerdo con los resultados químicos de la solución lixiviada, donde no se aprecia la existencia de Al. El segundo caso es objeto del apartado siguiente.

III. Microscopía electrónica de barrido y energía dispersiva de rayos $X$

Los estudios llevados a cabo por microscopía electrónica en la cenizas volantes muestran diferencias morfológicas, dependiendo de su origen y composición. with the chemical results from leached solution, in which the aluminium is not detected. The second case is studied by SEM.

\section{Scanning electron microscopy and X-ray dispersive energy microanalysis}

The studies of fly ashes carried out through SEM show the different morphology of such fly ashes depending on their origin and composition. So, the following can be observed.
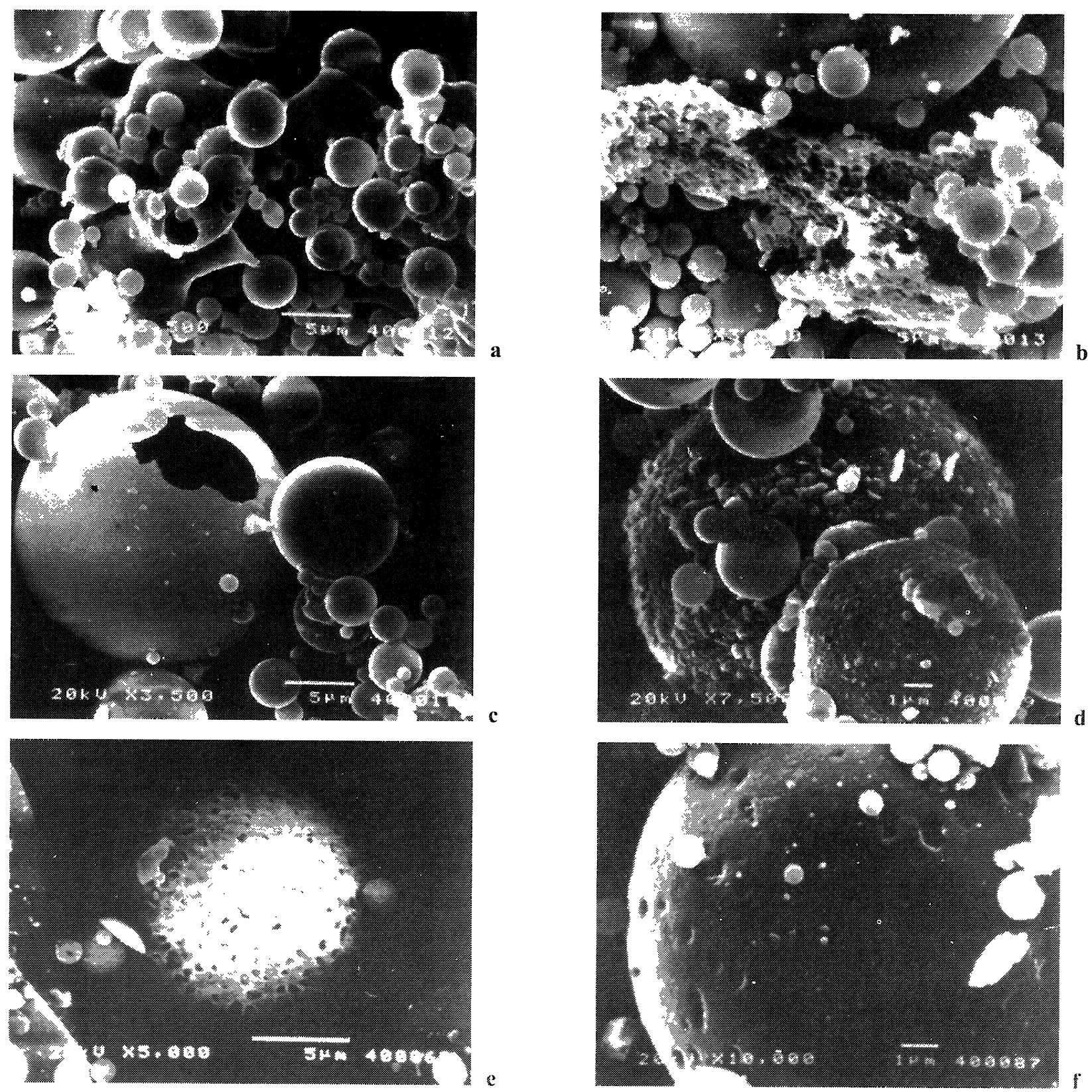

Figura 3.- Aspectos de FA-1 y LFA-1 por SEM/Figure 3.- FA-I and LFA-I aspect through SEM 
La ceniza FA-1 (baja en cal) presenta muchas partículas esféricas (Fig. 3a), partículas de carbón con pequeñas cenosferas en los huecos de su estructura abierta (Fig. 3b), plenosferas parcialmente rotas (Fig. 3c) y cenosferas rugosas con depósitos superficiales, en los que se observan la presencia de altos contenidos de hierro (Fig. 3d) (estudios llevado a cabo por EDX).

En la FA-2, con un contenido medio en cal, se observa la presencia de partículas irregulares ricas en calcio, mezcladas con partículas esféricas (Fig. 4a, 4b). Este efecto aumenta con el contenido de cal en la ceniza FA-3 (Fig. 5a y 5b)
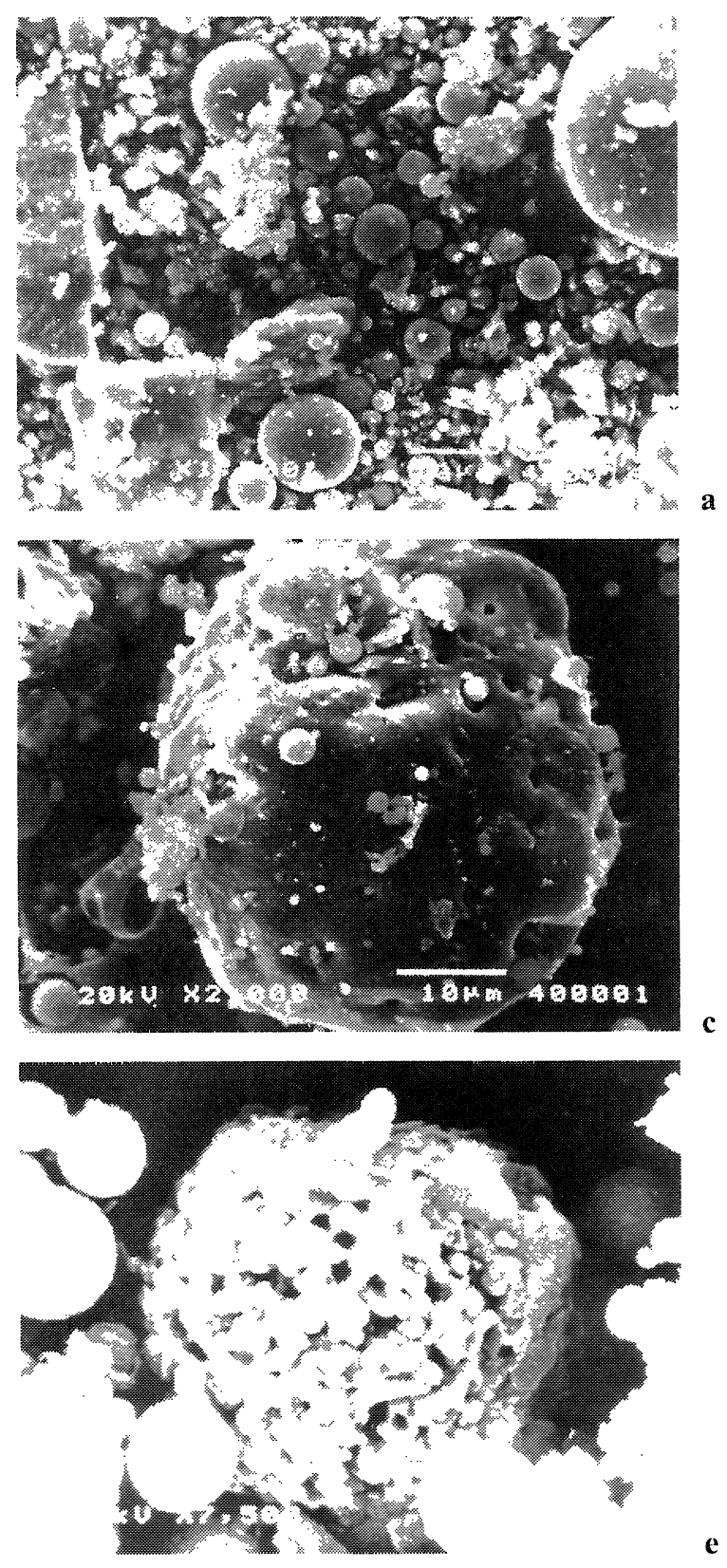

FA-1 fly ash (low lime content) presents a lot of spherical particles (Fig. 3a), carbon particles with small cenospheres deposited in the hollows of their open structure (Fig. 3b), partially broken plenospheres (Fig. 3c) and rough cenospheres with superficial deposits in which the presence of high iron contents are observed (Fig. $3 d$ ) (study carried out through $X$-ray dispersive energy, EDX).

In FA-2 fly ash, with medium lime content, a higher amount of irregular calcium rich particles is present, mixed with the spherical particles (Fig. 4a, 4b). This effect increases with $\mathrm{CaO}$ content in FA-3 (Fig. $5 a$ and $5 b$ ).
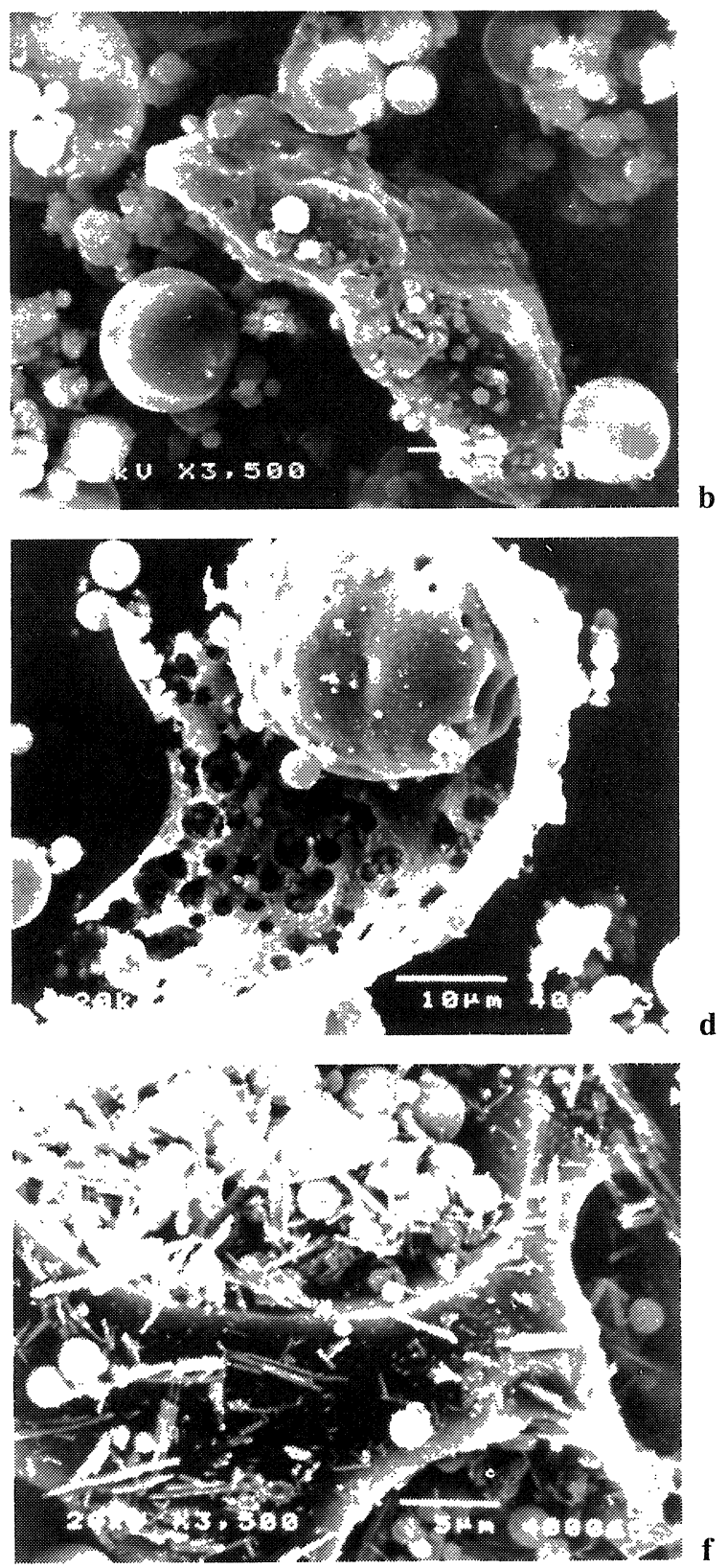

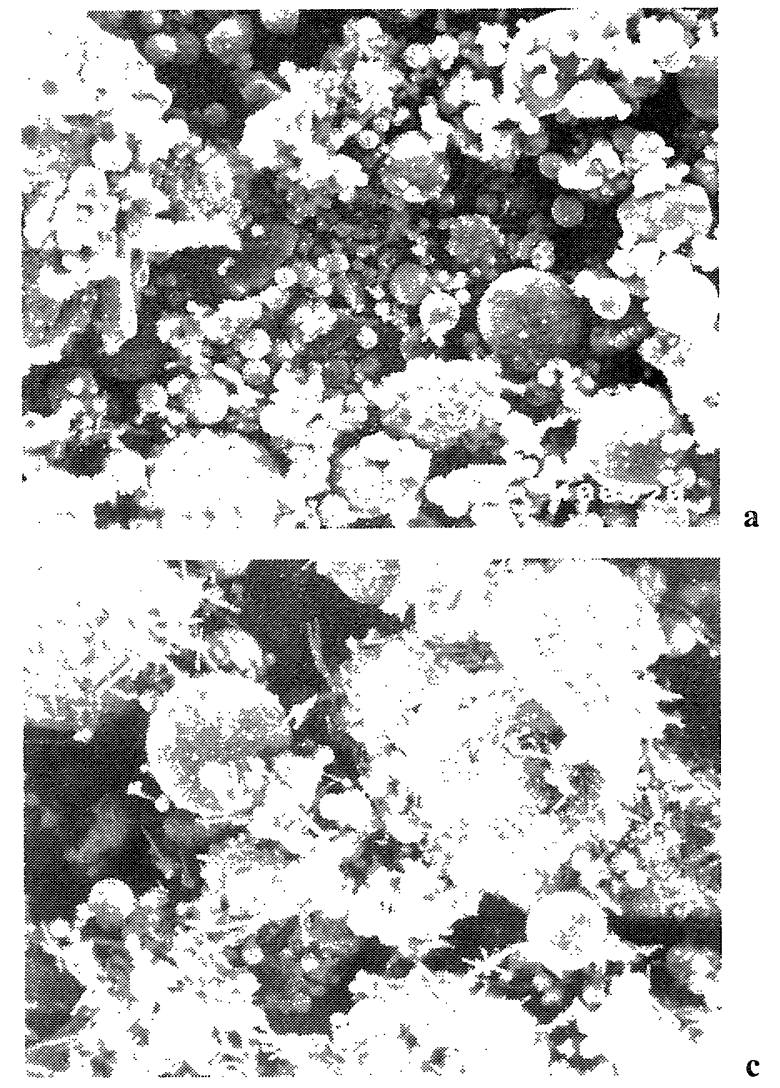
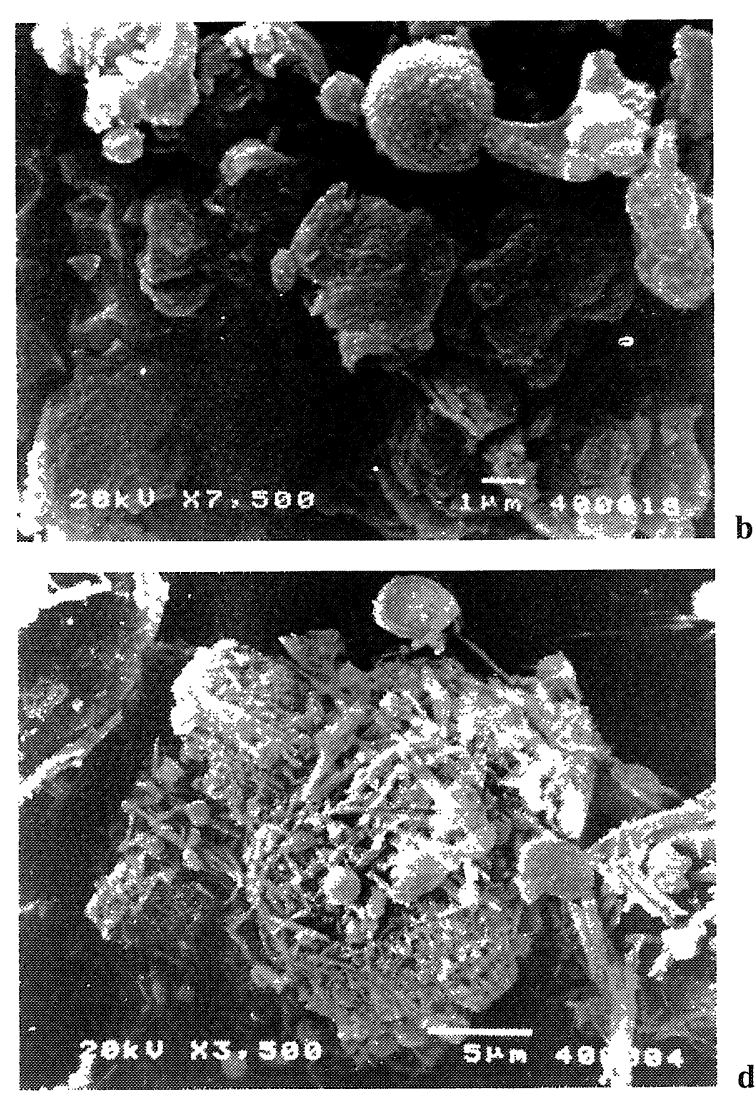

Figura 5.- Aspectos de FA-3 y LFA-3 por SEM./Figure 5. - FA-3 and LFA-3 aspect through SEM.

En general, los cambios morfológicos producidos por el fenómeno de lixiviación son más importante cuanto mayor es el contenidos en cal. Así, en la LFA-1 se detecta alteraciones superficiales en las cenosferas (Fig. 3e y $3 \mathrm{f}$ ), produciendo partículas con huecos de diferentes profundidades; mientras que las cenizas volantes, media y alta en cal (FA-2 y FA-3), el fenómeno de lixiviación produce la formación de agujas y placas (Figs. 4e, 4f, 5c y $5 d$ )

Los microanálisis realizados por EDX ponen de manifiesto que las agujas están formadas por calcio, aluminio, azufre y silicio (Fig. 6a y 6b). Cuyos porcentajes no se adaptan claramente a compuestos como etringita o monosulfato, por lo que se tratará de formaciones de composiciones variables, que no presentan cristalizaciones detectables por DRX (Fig. 2).

\section{CONCLUSIONES}

De acuerdo con los resultados obtenidos con tres cenizas volantes de diferente procedencia, se pone en evidencia que el fenómeno de lixiviación es muy complejo y, por lo
In general terms, morphological changes produced for leaching phenomenon are more important as calcium content increases. So, in FA-1 fly ash, superficial alterations in cenospheres are observed (Fig. 3e and 3f), giving place to particles with hollows of different depths; while fly ashes with medium and high lime content (FA-2 and $F A-3$ ) the leaching effect produces the needles and plaques formation (Figs. $4 e, 4 f, 5 c$ and $5 d$ ).

The microanalysis carried out by EDX show that needles are formed by calcium, aluminium, sulphur and silicon (Figs. $6 a$ and $6 b$ ). Percentages of these elements do not correspond clearly to compounds as ettringite or monosulfate, so the formations must have variable composition with crystallisation undetectable by RXD (Fig. 2).

\section{CONCLUSIONS}

According to the results obtained with three Spanish fly ashes of different origin, it must be remarked that the leaching phenomenon is very complex and 

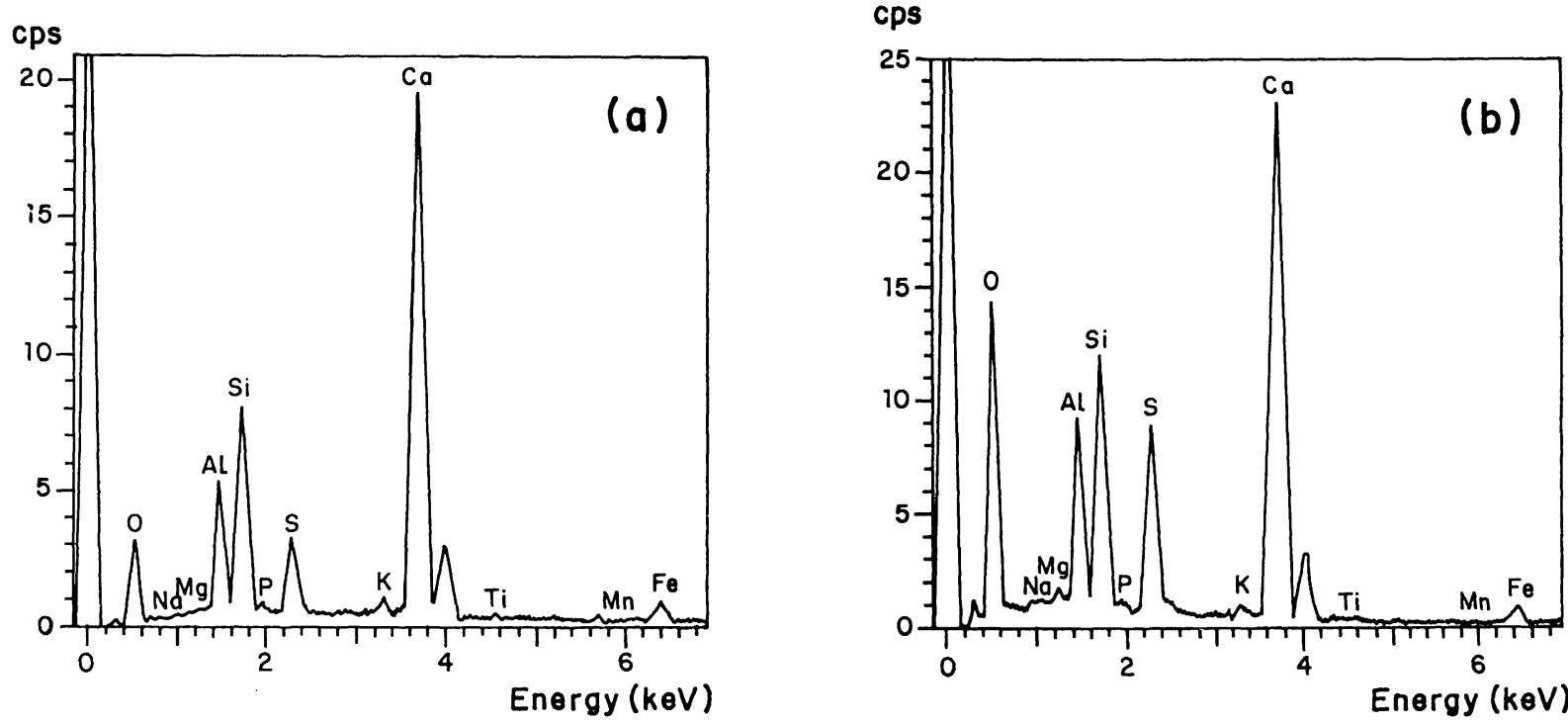

Figura 6.- Microanálisis por EDX.

Figure 6.- Microanalysis by EDX.

tanto, difícil de extrapolar a situaciones reales o a otras condiciones de ensayo. A pesar de ello, se puede obtener una orientación de la solubilidad de algunos de los elementos tóxicos presentes, así como los cambios estructurales ocasionados.

1. Como era de esperar, el porcentaje de elementos extraídos (mayoritarios y minoritarios) depende del $\mathrm{pH}$ de la solución. Así, los iones calcio y magnesio son fácilmente extraídos a $\mathrm{pH}$ ácido (FA-1 y FA-2); mientras que a pH básico (FA-3), su solubilidad disminuye notablemente.

2. Por otra parte y a priori, estas cantidades extraídas estarían relacionadas con las concentraciones iniciales antes del ensayo de lixiviación. Sin embargo, elementos como Mg y Mn a pH ácidos (FA-1 y FA-2) presentan diferencias en la lixiviación, a pesar de que sus concentraciones iniciales son muy parecidas. Este hecho pone de manifiesto que la solubilidad del compuesto, del que forma parte el elemento, tiene también un papel decisivo en los fenómenos de lixiviación.

3. Con respecto a los elementos alcalinos, los porcentajes extraídos de $\mathrm{Na}$ y $\mathrm{K}$ están situados entre un $2-4 \%$, valores relativamente bajos. Esto indica, que no todos los iones alcalinos presentes en las cenizas volantes están formando parte de compuestos solubles a los $\mathrm{pH}$ considerados a corto plazo (ejemplo, como sulfatos), por lo que serían necesarios tiempos de ensayo más largos, para obtener su valor máximo de lixiviación. therefore, it is difficult to extrapolate to real situations or other testing conditions. In spite of this, it must be obtained an orientation about the solubility of some of the toxic elements present in fly ashes as well as structural changes produced.

1. As it was expected, the percentage of the extracted elements (mayor and minor ones) depends on the solution $\mathrm{pH}$. So, calcium and magnesium ions are easily extracted at acid $\mathrm{pH}(F A-1$ and $F A-2)$ while their solubility decrease at alkaline $\mathrm{pH}(F A-3)$.

2. On the other hand, these amounts extracted would be related to initial concentrations before the leaching test. However, elements as $\mathrm{Mg}$ and $\mathrm{Mn}$ at acid $\mathrm{pH}$ (FA-1 and FA-2) have different leachates although their initial concentrations are similar. This fact shows how the compound solubility has an important role in leaching phenomena.

3. With respect to alkaline elements, the percentages of extracted $\mathrm{Na}$ and $\mathrm{K}$ are between 2 and $4 \%$, values relatively low. This shows that not all the alkaline ions present in fly ashes are forming compounds soluble at the pH considered at short term (as sulphates) and longer test times would be necessary to obtain a maximum value of leaching 
4. Los elementos tóxicos como $\mathrm{Cd}, \mathrm{Cu}, \mathrm{Ni}$ y $\mathrm{Pb}, \mathrm{y}$ elementos mayoritarios como $\mathrm{Al}$ y $\mathrm{Fe}$, forman parte de compuestos insolubles, tanto a $\mathrm{pH}$ ácido como a $\mathrm{pH}$ alcalino, al no detectarse en las aguas de lixiviado.

5. Los difractogramas de rayos $\mathrm{X}$ ponen de manifiesto que el $\mathrm{pH}$ ligeramente ácido (con ácido acético) no modifica la mineralogía de las cenizas volantes FA-1 y FA-2; sin embargo, en la FA-3 no ocurre lo mismo, lo que puede deberse al pH básico de esta ceniza. En la ceniza volante alta en cal (FA-3) se detecta la formación de nuevos compuestos cristalinos, como la calcita, aunque no se observa etringita, monosulfato o yeso.

6. Las técnicas de SEM y EDX muestran cambios morfológicos después del ensayo, más importantes cuanto mayor es el contenido de cal. En FA-3 se detecta la formación de pequeñas agujas, cuyo microanálisis podría corresponder a un compuesto cuya relación $\mathrm{Ca} / \mathrm{S}, \mathrm{Ca} / \mathrm{Al}$ y $\mathrm{Al} / \mathrm{S}$ varía entre la etringita y monosulfato. En cualquier caso estas formaciones presentarían estructuras no identificadas por DRX.

7. De todo lo expuesto anteriormente y desde el punto de vista medioambiental, los elementos minoritarios y tóxicos presentes en las cenizas volantes son bastante insolubles, ya que no se han extraído concentraciones superiores al $5 \%$, a excepción del Mn en la FA-2.

A pesar de estos porcentajes mínimos extraídos, estos subproductos industriales pueden tener un efecto negativo cuando éstos son depositados en escombreras o lugares no controlados, en los cuales los elementos tóxicos solubles pueden ser lixiviados por acción del agua de lluvia y acumularse en suelos y aguas subterráneas.

\section{AGRADECIMIENTO}

Este estudio pertenece a la investigación llevada a cabo en el Proyecto AMB94-0935 y financiada por CICYT (Comisión Interministerial de Ciencia y Tecnología, España).
4. Toxic elements as $\mathrm{Cd}, \mathrm{Cu}, \mathrm{Ni}$ and $\mathrm{Pb}$ and, mayor elements as $\mathrm{Al}$ and $\mathrm{Fe}$ form insoluble compounds (either acid or basic $p H$ ) not detected in leachate waters.

5. $X$ ray diffractograms show that slightly acid $p H$ (with acetic acid) does not modify the mineralogy of FA-1 and FA-2; however, it is different for FA-3 due to the alkaline $\mathrm{pH}$ of this fly ash in which the formation of new crystalline compounds as calcite is found, although ettringite, monosulfate or gypsum are not found.

6. SEM and EDX show morphological changes after the test, more important as lime content increases in the ashes. In FA-3, the formation of small needles, which microanalysis could correspond to a compound with ratios (Ca/S, Ca/Al and Al/S) between ettringite and monosulfate, but with an amorphous structure not detected by XRD.

7. From all these results and from an environmental viewpoint, minor and toxic elements present in fly ashes are quite insoluble, because they are not extracted in concentrations higher than 5\%, except for $M n$ in $F A-2$.

In spite of this minimum percentages extracted, these by-products may have a negative effect when they are left in uncontrolled places in which soluble toxic elements must be leached by rainwater action and pass through the ground and subterranean waters.

\section{ACKNOWLEDGEMENT}

This study belongs to the research carried out inside AMB94-0935 project and supported by CICYT (Comisión Interministerial de Ciencia y Tecnología, Spain).

\section{BIBLIOGRAFÍA}

(1) UNE 80301 96: Definiciones, clasificación y especificaciones de los cementos.

(2) ENV 197-1 92: Cement: Composition, specifications and Conformity criteria. Part 1: Common Cements.

(3) ASINEL (1994), Programade Investigación y Desarrollo Electrónico: Determinación y valoración de la lixiviación de las cenizas volantes para la prescrvación del medio ambiente.

(4) MAGTHOMSONC. yHARVEY M. NESS(1983): Engineering properties and leaching tendencies of resuse products containing lignite fly ashes CoalTechnol(Houston), v6, 235-261. 
(5) HOHBERG, I y RANKERS, I. (1994): Environmental aspects of construction with waste materials. Editors: Goumans J.M., Van der Sloot and Aalbers, T.G.. v.13,387-396.

(6) U.S. Environmental Protection Agency, Office of solid waste (1980): Appendix II-EP toxicit $/$ test procedure. Federal Register 45 (98), 33127.

(7) U.S. Environmental Protection Agency, Office of Research and Development. Environmental Monitoring and Support Laboratory. Methods for chemical analysis of water and waster. EPA-600/4-79-020.

(8) U.S. Environmental Protection Agency. Environmental Monitoring and Support Laboratory(1979): Inductively Coupled Plasma(ICP) Optical Emission Spectrometric Method for trace elements analysis of water and waster. Federal Register, 44 (233), 69559.

(9) BOE 10 nov. 1989: Orden 13 octubre 1989: Residuos Tóxicos Y Peligrosos. Métodos de Caracterización.

(10) NEN 7340. Leaching characteristics of building and solid waste materials- Leaching tests- General Instruction, Netherlands Normalisation Institute, The Netherlands.

(11) NEN 7341. Leaching characteristics of building and solid waste materials- Leaching tests-Determination of the availability of inorganic components for leaching (previously part of NVN2508); Netherlands Normalisation Institute, The Netherlands.

(12) NEN 7343. Leaching characteristics of building and solid waste materials- Leaching tests-Determination of the leaching of inorganic components from granular materials with the column test. (previously part. of NVN 2508); Netherlands Normalisation Institute, The Netherlands.

(13) NEN 7345. Leaching characteristics of building and solid waste materials- Leaching tests-Determination of the leaching of inorganic components from building materials, monolithic waste and stabilised waste materials (previously part of NVN 5432); Netherlands Normalisation Institute, The Netherlands.

(14) NEN 7349. Leaching characteristics of building and solid waste materials- Leaching tests-Determination of the leaching of inorganic components from granular materials, with the cascade test (previously part of NVN 2508); Netherlands Normalisation Institute, The Netherlands.

(15) ANS. 16.1. Measurements of the leachability of solidified low level radioactive wastes by a short term test procedure. American Nuclear Society, Illinois 60525 USA.

(16) ASTM D3987 81. American Society for Testing and Materials, 1983. Annual Book of ASTM Standards. Water and Environmental Technology. Part. 31, p1258.

(17) DIN 38414, par 4.German standard for water, wastewater and sludge. Determination of leachability with water . Institute fur Normung, Berlin.

(18) VAN DER SLOOT, H.A.; DE GROOT, G.J. y WIJKTRA, J. (1989): Leaching Characteristics of Construction Materials and Stabilisation Products Containing Waste Materials. American Society for Testing and Materials, Philadelphia, 125-149

(19) VAN DER SLOOT, H.A. (1990): Leaching behaviour of waste and stabilised waste materials: Characterisation for environmental assessment purposes. Waste Management and Research, 8, 215-228.

(20) VAN DER SLOOT, H.A; COMANS, R.N.J.; VAN DER HOEK, E.E. ; DE GROOT, G.J. (1992): Classification of pulverised coal ash. Part. I: Leaching behaviour of coal fly ash. ECN-C- 93-059.

(21) VAN DER SLOOT, H.A.; DE GROOT, G.J. y WIJKTRA, J. (1993): Classification of pulverised coal ash. Part II: Leaching properties of concrete with pulverised coal fly ash as partial cement replacement. ECN-C-93-064.

(22) BLOEM, P.J.C.; LAMERS, F.L.M.; TAMBOER, L. (1994): Leaching Behaviour of building materials with by-products under practical conditions. Stud. Environ. Sci., 60, 195-204.

(23) HASSETT, D.J.; HENKE, K.R.; MCCARTHY, G.J. (1986): Leaching behaviour of fixed-bed gasification ash derived from North Dakota lignite. Mat. Res. Symp. Proc., 65 (Materials Research Society), 285-300.

(24) RANKERS, R.H.; HOHBERG, I. (1991): Leaching tests for concrete containing fly ash - evaluation and mechanism. Stud. Environ. Sci., 48, 275-282.

(25) HOHBERG, I.; RANKERS, R. (1994): Leaching properties of cement-bound materials. Stud. Environ. Sci., 48, 275-282, 60, 387-398. 
(26) SÁNCHEZ DE ROJAS, M.I.; LUXÁN, M.P. y FRÍAS, M. (1986): La espectrometría de emisión con fuente de plasma de acoplamiento inductivo. Materiales de Construcción, v.36, n. 202, 31-46.

(27) ROY, R. W.; THIERY, R.G.; SCHULLER, R.M. y SULOWAY, J.J. (1983): Chemical and toxicological properties of coal fly ash. Illinois State Geological Survey. Environ. Geo. Notes, 105, 70.

(28) EARY, L.E.; DHANPAT R.; MATTIGOD, S.V. y AINSWORTH, C.C.(1990): Geochemical factors controlling the mobilisation of inorganic constituents from fossil fuel combustion residues: II. Review of the minor elements. J. Environ. Qual., 19, $202-214$.

(29) FRÍAS, M. y SÁNCHEZDE ROJAS, M.I.(1995): Determination and quantification of total chromiumand water soluble chromium contents in commercial cements. Cement and Concrete Research, v.25, n.2, 433-439.

(30) DIAMOND, S. y LÓPEZ-FLORES, F. (1981): On the distinction in physical and chemical characteristics between lignitic and bituminous fly ashes. Mater. Res. Soc. Ann. Meet., Boston, 34-44.

(31) ROHATGI, P.K.; HUANG, P.; GUO,R.; KESHAVARAM, B. y GOLDEN, D. (1995): Morphology and selected properties of fly ashes. Fifth CANMET/ACI, Fly ash, Silica fume, Slag and natural pozzolan in concrete. Editor: V.M. Malhotra, SP153-26, v.1, 459478.

(32) LUXÁN,M.P.;SÁNCHEZDEROJAS,M.I.yFRÍAS, M.(1989): Investigations on the fly ash-calciumhydroxidereactions. Cement and Concrete Research, v.19, n.1, 69-80.

\section{publicación del IETCC/CSIC}

\section{JORNADAS SOBRE CEMENTO ALUMINOSO}

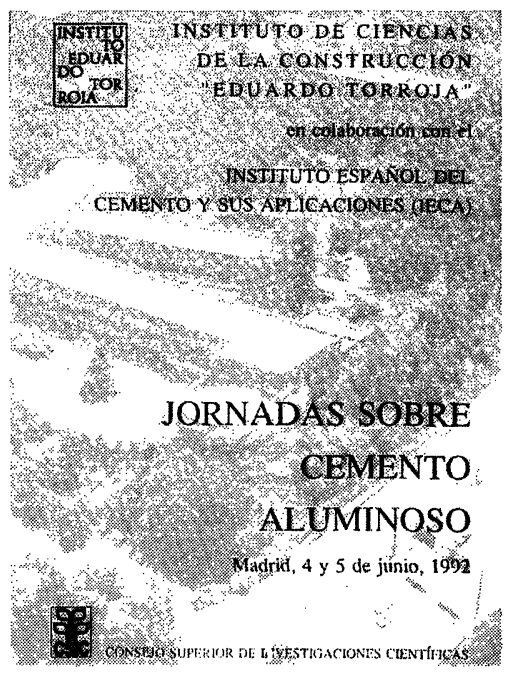

El Instituto Eduardo Torroja publica integramente -en colaboración con el Instituto Español del Cemento y sus Aplicaciones (IECA) - las “Jornadas sobre cemento aluminoso", celebradas en junio de 1992.

Se recogen las conferencias dictadas por destacados especialistas en la materia, asi como las intervenciones suscitadas en los coloquios y en la interesante Mesa Redonda, tras la cual se clausuraron las Jornadas.

El tratamiento dado al tema del hormigón y cemento aluminoso por los intervinientes abarca tanto aspectos rigurosos científico-técnicos como de índole práctica, abordando temas de corrosión de armaduras, durabilidad, protección y reparación de los elementos constructivos con daños causados por diversas motivaciones ampliamente expuestas.

Este libro será, sin duda, una eficaz ayuda tanto para el científico o el técnico estudioso de esta materia, como para aquellos profesionales interesados en un tema de tanta importancia y actualidad como es el relacionado con los hormigones de cemento aluminòso.

Un volumen de $15,5 \times 22,5 \mathrm{~cm}, 186$ págs., con figuras de línea, gráficos, tablas, etc. 